\title{
Yatırılarak İzlenen Anoreksiya Nervozalı Ergenlerde Yeniden Beslenme Döneminde Hipofosfatemi Gelişme Riski
}

\author{
Refeeding Hypophosphatemia Risk in Adolescent Inpatients with \\ Anorexia Nervosa During Nutritional Rehabilitation
}

๑Melis PEHLIVANTÜRK KIZILKAN, •Sinem AKGÜL, • Orhan DERMAN, ๑Nuray KANBUR

Hacettepe Üniversitesi Tıp Fakültesi Çocuk Sağlığı ve Hastalıkları Anabilim Dalı, Ergen Sağlığı Bilim Dalı, Ankara

ÖZ

Amaç: Anoreksiya nervozada (AN) yeniden beslenme döneminde, hipofosfatemi en sık görülen elektrolit bozukluğudur ve "refeeding sendromu" gelişmesi riskini saptamada oldukça duyarlı bir belirteçtir. Yeniden besleme protokolleri merkezler arasında farklııklar göstermektedir ve bunların hipofosfatemi gelişimine etkileri araştıılmaktadır. Bu çalışmanın amacı, merkezimizde AN tanısı ile izlenen ve yatırılan ergenlerin yeniden beslenme döneminde hipofosfatemi gelişme oranını ve risk etmenlerini belirlemektir.

Gereç ve Yöntemler: Ocak 2010 ve Temmuz 2019 arasında Çocuk Hastanesi Ergen Sağlığı Bölümünde AN tanısı ile izlenen ve yatış kriterlerini karşıladığı için beslenme rehabilitasyonu ve medikal stabilizasyon amacıyla serviste yatırılarak takip edilen, yaşları 11-18 arasında değişen 58 hastanın 64 yatışına ait dosya bilgileri geriye dönük olarak yeniden beslenme döneminde hipofosfatemi gelişimi ve etken olabilecek parametrelere yönelik taranmıştır.

Bulgular: Toplamda 24 (\%37.5) yatış sırasında yeniden beslenme döneminde hipofosfatemi gelişmiştir ve fosfor desteği verilmiştir. Hipofosfatemi gelişen ve gelişmeyen hastalar karşılaştıııldı̆̆ında, hipofosfatemi gelişen grubun yaş ortalaması daha yüksek ( $p=0.01)$, hastalık başlangıcından yatışa kadar geçen süre daha uzun ( $p=0.001)$, kaybedilen vücut ağırlığı miktarı $(\mathrm{p}=0.013)$ ve yüzdesi $(\mathrm{p}=0.002)$ daha fazla ve yatış sırasındaki BKI z skoru $(\mathrm{p}=0.001)$ anlamlı olarak daha düşük bulunmuştur.

Sonuç: Bu çalışmada yaş, yatışa kadar geçen hastalık süresi ve malnutrisyon derecesi yeniden beslenme dönemindeki hipofosfatemi gelişimini belirleyen temel etmenler olarak bulunmuştur. Beslenme protokolünün her hasta özelinde değerlendirilmesi ve özellikle ağır malnutrisyonlu hasta grubunda daha dikkatli olunması, fosfor seviyelerinin günlük takibi ve fosfor desteğinin uygun şekilde verilmesi çok önemlidir.

Anahtar Sözcükler: Anoreksiya Nervoza, Ergenlik Dönemi, Hipofosfatemi, Risk Etmenleri, Yatan Hasta, Yeniden beslenme dönemi

\begin{abstract}
Objective: In patients with anorexia nervosa (AN), refeeding hypophosphatemia is the most common electrolyte imbalance during nutritional rehabilitation and an essential marker predicting the risk of refeeding syndrome. Clinical approaches regarding refeeding protocols vary largely and their effect on refeeding hypophosphatemia has been an intriguing research area. This study evaluated the prevalence of refeeding hypophosphatemia and associated risk factors in adolescent inpatients with AN.

Material and Methods: Between January 2010 and July 2019 we retrospectively evaluated the 64 hospitalizations of 58 patients (mean age: 14.84 1.58 years) followed Adolescent Medicine Clinic for refeeding hypophosphatemia and associated risk factors.

Results: Oral phosphorus supplementation was given to 24 (37.5 \%) patients due to refeeding hypophosphatemia. When patients were compared according to the presence of refeeding hypophosphatemia, the hypophosphatemia group has significantly older age $(p=0.01)$, lower BMI z score at admission $(p=0.001)$, higher amount $(p=0.013)$ and percentage of weight loss ( $p=0.002)$, and longer duration of illness $(p=0.001)$.

Conclusion: This study demonstrated that age, duration of illness, and degree of malnutrition are the significant contributors to refeeding hypophosphatemia. Regulating refeeding protocols specific to the patient's needs close monitoring of serum phosphorus levels and appropriate management of hypophosphatemia is essential, especially in patients with severe malnutrition.
\end{abstract}

Key Words: Anorexia Nervosa, Adolescent, Risk Factors, Inpatient, Refeeding hypophosphatemia

Yazıșma Adresi / Correspondence Address:

\section{Melis PEHLIVANTÜRK KIZILKAN}

Hacettepe Üniversitesi Tıp Fakültesi Çocuk Sağlığı ve Hastalıkları Anabilim Dalı,

Ergen Sağlığı Bilim Dalı, Ankara, Türkiye

E-posta: melis.pehlivanturk@hacettepe.edu.tr
Geliş tarihi / Received : 30.07.2019 Kabul tarihi / Accepted : 03.10.2019 Elektronik yayın tarihi : 10.03 .2020 Online published

DOI: 10.12956/tchd.598217 


\section{GiRiş}

Anoreksiya nervoza (AN) hastalarında beslenme rehabilitasyonu ve vücut ağırlığının tekrar kazanımı, kısa ve uzun dönemdeki komplikasyonların çoğunun önüne geçilmesinde en önemli basamaklardandır. Öte yandan, yeniden beslenmenin başlandığı dönemde hastalar yeniden beslenme ("refeeding") sendromu açısından risk altındadır ve refeeding sendromu (RFS) özellikle yol açtığı sıvı ve elektrolit dengesindeki bozukluklar nedeniyle morbidite ve mortalitesi yüksek bir durumdur (1). RFS, malnütrisyonu olan bir hastanın oral, enteral ya da parenteral yeniden beslenmesi sırasında ortaya çıkan klinik ve metabolik bozukluklar olarak tanımlanmaktadır (2). Mortaliteden en çok sorumlu olan elektolit bozuklukları hipokalemi ve hipofosfatemi olmakla beraber RFS sırasında gelişebilecek diğer metabolik bozukluklar ve kardiyak, pulmoner, gastrointestinal ve nörolojik komplikasyonlar yönünden dikkatli olunmalıdır.

Refeeding sendromu riskini artıran etmenler arasında düşük beden kitle indeksi (BKi), hızlı kilo kaybı, beş günden uzun süren gıda reddi ve yeniden beslenme dönemi öncesinde var olan elektrolit bozukluğu yer almaktadır (3). RFS riskinin en aza indirilmesi konusunda global olarak benimsenmiş bir beslenme rehabilitasyonu protokolü yoktur. Uygulanan yöntemler daha çok klinik deneyimlere ve sınırlı sayıda çalışmadan elde edilen verilere dayanmaktadır. Son yıllarda ekonomik endişeler ya da yatış bekleyen hasta yoğunluğu nedeniyle hastanede yatış süresini azaltmaya yönelik daha yüksek kalori ile beslenmeye başlanılan ve kalori artımının daha hızlı yapıldığı protokoller gündeme gelse de, özellikle ağır malnutrisyonu olan grupta düşük kalori ile başlanıp yavaş kalori artımının daha güvenli olduğu görüşü hakimdir (4-6).

RFS sırasında en sık görülen elektrolit bozukluğu hipofosfatemidir ve RFS'deki medikal komplikasyonların çoğu tedavisiz ağır hipofosfatemiye ikincil geliştiğinden hipofosfatemi riski saptamada oldukça duyarlı bir belirteçtir $(4,7)$. RFS sırasında hipofosfatemi gelişimini en çok belirleyen risk faktörü düşük BKI olarak belirlense de, farklı merkezlerde uygulanan yeniden beslenme protokollerinin ve RFS'yi önlemeye yönelik uygulanan yöntemlerin, hipofosfatemi gelişimi üzerindeki etkisini değerlendirmek için daha çok klinik çalışmaya gereksinim vardır (8). Bu çalışmanın amacı, üçüncü basamak bir hastanede AN tanısı ile serviste yatırılarak izlenen ergenlerin yeniden beslenme döneminde hipofosfatemi gelişme oranını ve risk etmenleri belirlemektir.

\section{GEREÇ ve YÖNTEM}

Ocak 2010 ve Temmuz 2019 arasında Çocuk Hastanesi Ergen Sağlığı Bölümünde AN tanısı ile izlenen ve yatış kriterlerini karşıladığı için beslenme rehabilitasyonu ve medikal stabilizasyon amacıyla serviste yatırılarak takip edilen, yaşları 11-18 arasında değişen 58 hastanın 64 yatışına ait dosya bilgileri geriye dönük olarak taranmıştır. Hastalardan 3 tanesi 2 kez, 1 tanesi 4 kez yatırılarak takip edilmiştir. AN dışı yeme bozuklukları ve tıbbi yatış kararına rağmen kendi istekleri ile ilk hafta içerisinde hastaneden ayrılan hastalar refeeding dönemi atlanacağı için çalışma dışında bırakılmıştır. Tüm hastaların tanıları DSM5 yeme bozukluğu tanı kriterlerine göre değerlendirilmiştir. 2013 öncesinde DSM-IV TR tanı kriterlerine göre tanı alan hastaların da klinik bilgileri gözden geçirilerek, DSM-5'e göre tanıları düzenlenmiştir. Hastaların yatış vücut ağırlığı ve boy ölçümleri kayıt edilmiştir. Yatış vücut ağılığı hastaların hastaneye yattıktan sonraki ilk gün sabah kahvaltı öncesi ve idrar çıkarımı sonrası hastane önlüğü ile ölçülen vücut ağırlığıdır. Beden kitle indeksi (BKI), vücut ağırlığı $(\mathrm{kg})$ boyun karesine $\left(\mathrm{m}^{2}\right)$ bölünerek hesaplanmıştır. BKI z skorları cinsiyete ve yaşa göre "Center for Disease Control and Prevention" (CDC) büyüme eğrilerine göre hesaplanmıştır (9). BKI z skoru -1 ve -1.9 arasında olanlar hafif, -2 ve -2.9 arasında olanlar orta ve -3 ve daha düşük olanlar ağır malnutrisyon olarak sınıflandırılmıştır (10). Yakınmaların ortaya çıkışından yatışa kadar geçen süre, bu sürede kaybedilen vücut ağırlığı miktarı ve yüzdesi, yatış sırasında başlanan günlük kalori miktarı, taburculuk sırasında tüketilen günlük kalori miktarı, taburculuk vücut ağırlığı, BKI ve BKI z skoru, taburculuk ve yatış arasındaki vücut ağırlığı ve BKi farkları, eşlik eden ödünleyici davranış varlığı ve tipi, beslenme rehabilitasyonuna yönelik enteral ürün ve nazogastrik sonda kullanımı, yatış süresi, hipofosfatemi gelişimi, serum fosfor düzeyi, fosfor düzeylerinin normal seviyeye ulaşma süresi, uygulanan tedavinin süresi ve vücut ağırlığı artış hızına ait veriler kayıt altına alınmıştır. Vücut ağırlığı artış hızı, yatış ve taburculuk vücut ağırlığı farkının, yatış süresine (gün) bölünmesi ile hesaplanmıştır. Kaybedilen vücut ağırlığı yüzdesi, kaybedilen vücut ağırlı̆ı miktarının (kg) hastalık öncesi vücut ağırlığına $(\mathrm{kg})$ bölünmesi ile hesaplanmıştır. Fosfor düzeyinin 3 mg/dl altında olması çoğu yeme bozukluğu kliniğinde olduğu gibi bizim kliniğimizde de hipofosfatemi olarak kabul edilmiştir (11). Hipofosfatemi derecelendirmesinde farklı görüşler bulunmakta birlikte bu çalışmada konu ile ilgili daha önce yapılan çalışmalar dikkate alınarak fosfor seviyesi $\geq 2.5$ ve $<3 \mathrm{mg} / \mathrm{dl}$ ise hafif düzeyde, fosfor seviyesi $\geq 1$ ve $<2.5 \mathrm{mg} /$ dl ise orta düzeyde ve fosfor seviyesi $<1 \mathrm{mg} / \mathrm{dl}$ ise ağır düzeyde hipofosfatemi olarak derecelendirilmiştir $(12,13)$.

Hastalar "Society for Adolescent Health and Medicine" yönergelerine göre aşağıdaki yatış kriterlerinden bir ya da daha fazlasını sağladıkları durumda pediatri servisine yatırılarak izlenmiştir (14): Ağır malnutrisyon (ideal vücut ağırlığının \% 75'inin altında olmak), ayaktan izlemde tedavinin başarısızlığı, vital bulguların stabil olmaması (bradikardi: kalp atım hızının 45 atım/ dakika altında olması, hipotansiyon, hipotermi, ortostatik nabız değişikliği, ortostatik kan basıncı değişikliği), ağır dehidratasyon, kardiyak aritmi, elektrolit bozuklukları, akut gıda reddi, kontrol edilemeyen kusma/çıkarma davranışı, eşlik eden tıbbi ya da psikiyatrik hastalığın kontrol altına alınamaması. Hastane yatışı 
sırasında tüm hastalar çocuk sağlığı ve hastalıkları (ergen sağıı̆ı) uzmanı, çocuk ve ergen ruh sağlığı uzmanı ve beslenme ve diyetetik uzmanı tarafından takip edilmiştir. En az ardışık iki gece boyunca uyku sırasında kalp atım hızı 45 atım/dakika'nın altına hiç inmediği görülene kadar bradikardi ve aritmiler açısından sürekli kardiyak monitorizasyon yapılmıştır. Medikal stabil olmayan hastalar mutlak yatak istirahatine alınmıştır. Hastaların vital bulguları yakın aralıklarla takip edilmiştir ve sabah ölçümleri sırasında ortostatik nabız ve kan basıncı değerlerine de bakılmıştır. Taburculuk kararı medikal stabil olan ve beslenme rehabilitasyonu sağlanmış hasta grubunda ergen sağlığı ve çocuk ve ergen ruh sağlığı bölümlerinin ortak kararı ile alınmıştır.

Beslenme rehabilitasyonu hastaların yatış öncesi almakta olduğu günlük kalori detaylı beslenme öyküsü ile hesaplanarak ve o zamana kadarki beslenme içeriği göz önünde bulundurularak, günlük tüketmesi gereken miktar ayarlanacak şekilde planlanmıştır. Günlük 750 kilokalori (kkal) altında tüketen ergenlere $750 \mathrm{kkal} /$ gün olacak şekilde beslenme desteği başlanırken, günlük 750 kkal ve üzerinde tüketen ergenlerin beslenme miktarı aldıkları toplam kalori miktarının 250 kkal üzerinde olacak şekilde artırımıştır. Yatış sırasında 750 kkal üç ana öğüne bölünecek şekilde verilmiştir. Kalori artımı sağlandıktan sonra 3 ana 3 ara öğün olacak şekilde beslenme planı yapılmışıı. Sabahları aynı saatte, kahvaltı öncesi ve idrar boşaltımı sonrası, hastane önlüğü ile günlük vücut ağırlığı ölçümü yapılmıştır. Vücut ağırlığındaki artışa ve serum elektrolit tablosuna göre günlük kalori tüketimine karar verilmiştir. RFS'nin önüne geçebilmek için haftalık 1 kg'llk vücut ağırlığı artışı hedefi konularak, günlük 200 gram ve üzerinde vücut ağırlı̆ı artışlarında kalori arttıımı yapılmazken, daha az artış durumunda günlük 250 kkal artııımıştır (15).

Illk bir hafta RFS yönünden tüm hastaların günlük serum elektrolit ve glukoz seviyeleri kontrol edilmiştir. Gerekli durumlarda daha uzun süreli laboratuvar ölçümleri yapılmışıı. Hiçbir hasta profilaktik olarak fosfor desteği almamıştır ve hiçbir hastada serum fosfor seviyelerinde düşüşe neden olabilecek ilaç kullanımı yoktur. Bu çalışma Hacettepe Üniversitesi Girişimsel olmayan Klinik Araştırmalar Etik Kurul'u tarafından onaylanmıştır.

\section{İstatistiksel analiz:}

Değişkenlerin dağlımına Kolmogorov-Smirnov testi ile bakılmışıı. Tanımlayıcı veriler ortalama değer \pm standart sapma olarak verilmiştir. Hipofosfatemi gelişen ve gelişmeyen gruplar arasındaki karşılaştırma normal dağılım gösteren değişkenler için bağımsız gruplar t-testi, göstermeyenler için Mann-Whitney $U$ testi kullanılarak yapılmıştır. Fosfor değerlerine göre normal dağllım gösteren değişkenlerin karşılaştırması ANOVA, normal dağılım göstermeyen değişkenlerin karşılaştırması ise Kruskall Wallis testi ile yapılmıştır. Hipofosfatemi düzeyine niteliksel bağımsız değişkenlerin etkisine Ki-kare testi ile bakılmışıı. İstatistiksel anlamlılı 0.05 'in altındaki $p$ değerleri için kabul edilmiştir.

\section{BULGULAR}

Geriye dönük olarak 58 hastanın 64 yatışına ait veriler taranmıştır. Bu yatışların 53'ü (\%82.8) kadın hastalara aittir. Yatışların 43'ü (\%67.2) AN kisıtlayıcı tip ("restrictive type", ANRT), 15'i (\%23.4) AN tıkınırcasına yeme-çıkarma tipi ("binging purging type", ANBP) ve 6's (\%9.4) atipik AN tanılarıly izlenmiştir. Hastaların ortalama yaşı $14.84 \pm 1.58$ yıldır. Yatış anındaki ortalama vücut ağırlığı $39.95 \pm 8.20 \mathrm{~kg}$ ve ortalama BKI $15.08 \pm 2.43 \mathrm{~kg} / \mathrm{m}^{2}$ 'dir. BKI z skorlarına göre 30 (\%46.9) hastanın hafif, 11 (\%17.2) hastanın orta ve 23 (\%35.9) hastanın ağır düzeyde malnutrisyonu vardır. Hastaların ortalama yatış süresi $25.02 \pm 14.60$ gündür. Yatış sırasında başlanan ortalama kalori miktarı 1051 \pm 352 (minmax:750-1750) kkal'dir. Taburculuk anında ortalama tüketilen kalori miktarı 2426 \pm 492 (min-max: 1500-3500) kkal'dir.

Toplamda 24 (\%37.5) yatış sirasında yeniden beslenme döneminde hipofosfatemi gelişmiştir ve fosfor desteği verilmiştir. Tekrarlayan yatışlar göz önünde bulundurulmadığında, hastaların \%32.2 sinde hipofosfatemi gelişmiştir. Yatışlardan 18'i (\%75.0) ANRT tanısıyla, 5'i (\%20.8) ANBP (\%4.2) ve biri (\%4.2) atipik AN tanısıla izlenmiştir. Hasta tanılarına göre hipofosfatemi gelişme oranı karşılaştıııldı̆ında, ANRT grubunda en yüksek oran saptanmasına rağmen gruplar arasında anlamlı fark bulunamamıştır ( $p=0.456)$. Tüm hipofosfatemi olgularına fosfor desteği verilmiş ve bunların 19'unda (\%79.2) hafif düzeyde (fosfor seviyesi $\geq 2.5$ ve $<3 \mathrm{mg} / \mathrm{dll}$ ), 5'inde (\%20.8) ise orta düzeyde (fosfor seviyesi $\geq 1$ ve $<2.5 \mathrm{mg} /$ dl) hipofosfatemi görülmüştür. Hiçbir hastada ağır hipofosfatemi (fosfor seviyesi $<1 \mathrm{mg} / \mathrm{dll}$ ) gelişmemiştir. Oral fosfor replasmanı başlandıktan sonra ortalama serum fosfor düzeyinin normal seviyeye ulaşma zamanı $3.00 \pm 2.22$ (minimum-maksimum değer: 1-9 gün) gündür. Fosfor düzeyi bir hastada yedi, diğer hastada dokuz gün içerisinde düzelmiştir. Bu iki hasta dışında fosfor düzeyinin normal seviyeye dönmesi en fazla dört gün içerisinde olmuştur. Serum fosfor düzeyi dokuz gün içerisinde düzelen hastanın tedaviye uyumsuzluğu ve dirençli kusması olması, yedi gün içerisinde düzelen hastanın ise kliniğimize başvurusu öncesi beş ylllık iyi tedavi edilmemiş ağır malnutrisyon öyküsü olması nedeniyle genel popülasyonun refeeding özelliklerini yansıtmamaktadır. Serum fosfor düzeylerine göre klinik parametrelerin karşılaşıırması Tablo I'de verilmiştir.

Hipofosfatemi gelişen ve gelişmeyen hastalar karşılaştııldığında, hipofosfatemi gelişen grupta yaş, yatışa kadar geçen süre, vücut ağıllğı kaybı miktarı ve yüzdesi, yatış sırasındaki BKI z skoru anlamlı olarak farklı bulunmuştur. Hipofosfatemi gelişen

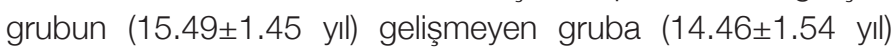
göre yaş ortalaması anlamlı olarak daha yüksektir ( $p=0.01$ ). Yakınmaların başlamasından yatışa kadar geçen süre hipofosfatemi gelişmeyen grupta $(8.39 \pm 9.05$ ay), gelişene göre (20.46 \pm 18.01 ay) belirgin olarak daha kısadır ( $p=0.001)$. Benzer şekilde hastalık başlangııından yatışa kadar kaybedilen vücut ağırlı̆ı miktarı ve yüzdesi hipofosfatemi gelişen grupta (24.08 $\pm 12.16 \mathrm{~kg}$ ve $\% 27.94 \pm 10.88)$, gelişmeyene (16.98 \pm 9.79 
Tablo I: Serum fosfor düzeylerine göre hastaların klinik verilernin karşılaştıııması.

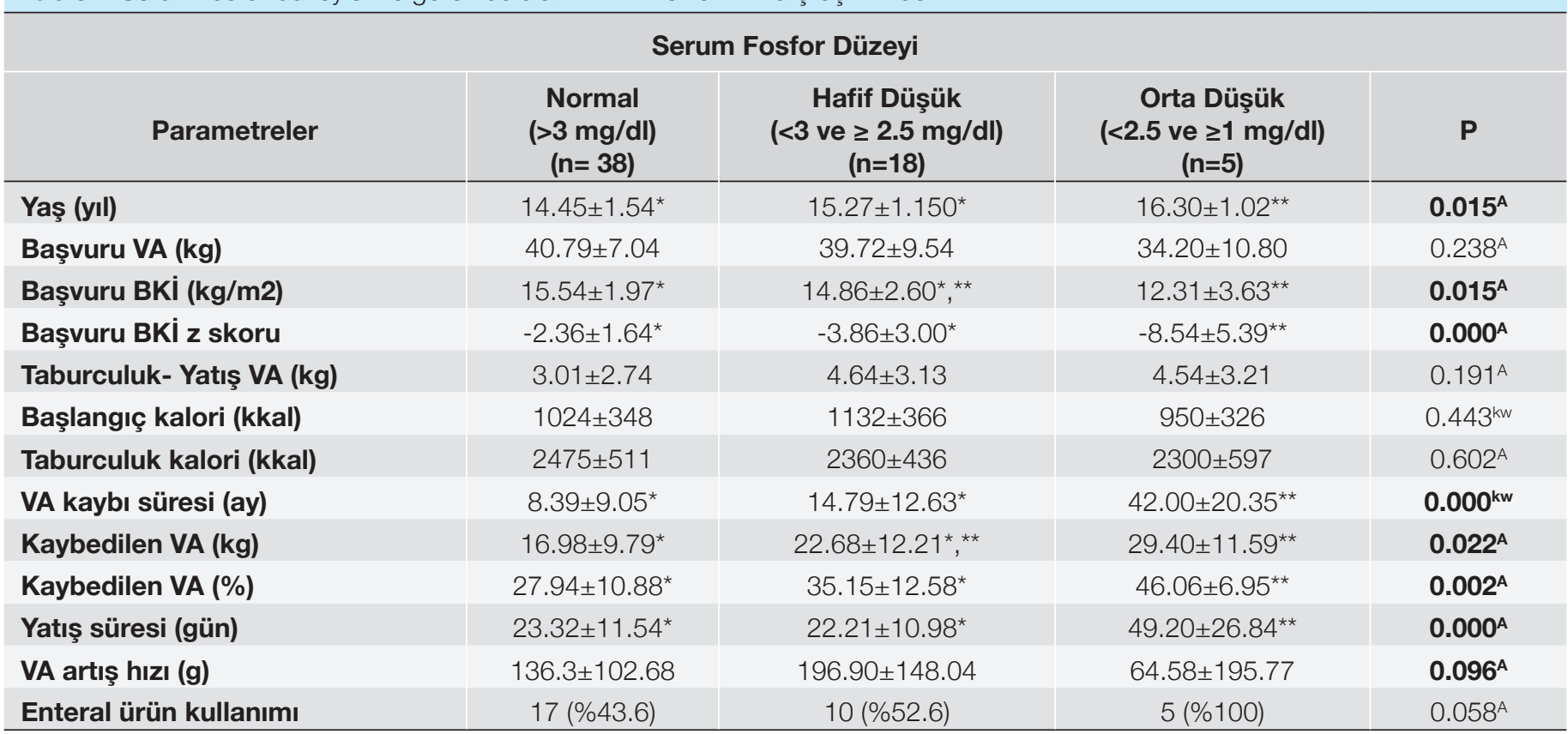

VA: Vücut ağırlığı, BKi: Beden kitle indeksi *,**: Fosfor düzeyine göre aralarında istatistiksel fark olan parametreler farklı gösterge ile işaretlenmiştir. kw: kruskal Wallis testi ile yapılan hesaplama, A: Tek-yönlü ANOVA testi ile yapılan hesaplamayı göstermektedir.

$\mathrm{kg}$ ve \%37.42 \pm 12.36 ) göre daha fazladır ( $\mathrm{p}=0.013$ ve $\mathrm{p}=0.002)$. Yatış sırasındaki BKi z skorları karşılaştııılığında hipofosfatemi gelişen grubun ortalama değeri (-4.68 \pm 4.05$)$, gelişmeyen gruba $(-2.31 \pm 1.59)$ göre belirgin daha düşüktür $(p=0.001)$. Yatış anındaki vücut ağırlığı $(p=0.298)$ ve BKi değerleri $(p=0.053)$, yatış ve taburculuk VA farkı ( $p=0.068)$, kilo alma hızı $(p=0.420)$, başlangıç ve taburculuk kalorileri arasında $(p=0.449$ ve $p=0.326)$ ise fark saptanmamiştır.

Hipofosfatemi (hafif ve orta düzeyde) gelişen hastalar gelişmeyenlere göre nazogastrik sonda kullanımı açısından değerlendirildiğinde, fosfor düzeyi normal olan hastaların 3'üne (\%37.5), fosfor düzeyi düşük olan hastaların ise 5'ine (\%62.5) beslenme rehabilitasyonu sırasında nazogastrik sonda uygulanmıştır $(\mathrm{p}=0.150)$. Fosfor düzeyi normal olan hastaların 10'unda (\%27.8), fosfor düzeyi düşük olan hastaların ise 9'unda (\%37.5) ödünleyici davranış bulunmaktadır ( $\mathrm{p}=0.428$ ). Ödünleyici davranışlar arasında illk sırada kusma yer alırken, ikinci sırada laksatif kullanımı vardır. İki hastada laksatif kullanımı ve kusma birlikteliği izlenmiştir. Hiçbir hasta kilo kaybetmeye yönelik olarak diüretik kullanmamıştır.

\section{TARTIŞMA}

$\mathrm{Bu}$ çalışma yatıılarak izlenen AN tanılı ergenlerde yeniden beslenme dönemi sırasında hipofosfatemi gelişme oranlarını ve hipofosfatemi gelişimine neden olan etmenleri değerlendirmiştir. Hipofosfatemi gelişme oranı \%37.5 olarak hesaplanmıştır. Tekrarlayan yatışlar göz önünde bulundurulmadığında, hastaların \%32.2 sinde hipofosfatemi gelişmiştir. Bu oran literatürdeki diğer çalışmalarla benzerdir. Yapılan farkıı çalışmalarda hipofosfatemi gelişme oranı \%11.0-47.3 arasında değişmektedir $(16,17)$. Bu çalışmalarda hipofosfatemi kabul edilen en düşük serum fosfor düzeyinin de farkllık gösterdiği göz önünde bulundurulmalıdır. Bir sistematik gözden geçirmede ortalama hipofosfatemi gelișme oranı \%14 olarak hesaplanmıştır (18). Brown ve ark. (19) tarafından yapılan bir çalışmada erişkin AN hastalarında hipofosfatemi gelişme oranı \%33.3 olarak saptanmıştı. Aynı çallşmada yüksek hemoglobin seviyesi hipofosfatemi riskini artırırken, yüksek serum potasyum ve prealbumin seviyeleri koruyucu faktör olarak bulunmuştur. Ornstein ve ark. (12) tarafindan yapılan çalışmada ise ergen yaş grubundaki 69 AN tanısı ile beslenme rehabilitasyonu amacıyla yatan hasta dahil edilmiş ve hipofosfatemi gelişme oranı \%27.5 olarak saptanmıştır.

Çalışmamızda hipofosfatemi gelişimine neden olan etmenler arasında yaş, hastalık başlangııından yatışa kadar geçen süre, bu sürede kaybedilen vücut ağırlığı miktarı, yatış sırasındaki BKI z skoru yer almaktadır. Fosfor düzeyine göre gruplar karşılaşııııldığında ise hipofosfatemi şiddetini aynı etmenler etkilemektedir. Bizim çalışmamıza benzer olarak Kameoka ve ark. (20) yaptığı bir çalışmada düşük BKI ve daha büyük yaş risk faktörü olarak saptanmıştır. Başka bir çalışmada 361 hastanın 461 yatışına ait veri geriye dönük olarak taranmış ve hipofosfatemi gelişimi düşük BKI ile ilişkili bulunurken, bizim çalışmamıza benzer şekilde kilo alım hızı ile ilişkilendirilmemiştir (8).

Beslenme rehabilitasyonu sırasında özellikle en riskli olan ilk haftada medikal komplikasyonların önlenmesinde kalori ve 
Sıvı alımının sınırlandırılması, günlük tüketilen kalori miktarının hızı artırımaması, klinik ve laboratuvar olarak hastanın yakın izlenmesi önerilmektedir. RFS gelişmesi durumunda tüketilen kalori konusunda daha da dikkatli olunmalıdır. "National Institute for Clinical Excellence" (NICE) yönergelerine göre RFS gelişimi açısından riskli olan hastalar düşük BKl'ye sahip olanlar, önceki 3-6 ay içerisinde \%10'un üzerinde kilo kaybı olanlar, 5 günden daha uzun süredir akut gıda reddi olanlar, RFS öncesi serum potasyum, fosfor, magnezyum seviyeleri düşük olanlar, alkol, madde kötüye kullanımı öyküsü ya da insülin, diüretik, antiasid kullanımı gibi ilaç kullanım öyküsü olanlardır (3, 4). AN tanısı olan ergenlerde yeniden beslenme sırasında oluşan hipofosfatemi risk faktörlerini araştıran bir sistematik gözden geçirmede hipofosfatemi gelişmesinde malnutrisyon derecesinin total enerji alımından daha önemli bir belirteç olduğu gösterilmiştir (18). Bizim çalışmamızda da orta dereceli hipofosfatemi gelişen grubun ortalama BKI ve BKI z skoru değerleri anlamlı olarak diğer gruplardan düşük olarak bulunmuştur. Benzer şekilde yatış sırasında yeniden beslenme için başlanan ve taburculuk sırasında tüketilen kalori miktarı ile yatıştan taburculuğa kadar gözlenen vücut ağırlığındaki artış oranı hipofosfatemi gelişimi ile ilişkili bulunmamıştır. Öte yandan hastaların hipofosfatemi geliştirdikleri döneme kadarki vücut ağırlığı ve tükettikleri kalorideki artış hızları hesaplanamamıştır. Ek olarak tüm hastalara yöntem kısmında anlatılan beslenme protokolü uygulanmıştır. Bu nedenle özellikle ağır malnutrisyonu olan hasta grubunda yatış öncesinde tüketmekte olduğu kalori miktarı hesaplanıp, ona uygun kaloride yeniden beslenme desteği başlanması ve elektrolit dengesi ve kilo alım hızına göre yavaş kalori arıtımı yapılması RFS riskinin en aza indirilmesinde çok önemlidir.

Her ne kadar RFS gelişimi konusunda düşük kalori ile başlanıp, yavaş kalori artımı savunulsa da son yıllarda tecrübeli merkezlerde daha agresif yaklaşımları içeren yeni protokoller de gündeme gelmiştir. Bazı çalışmalarda özellikle hafif ve orta malnutrisyonu olan grupta düşük kalori ile başlanıp kalorininyavaş yükseltilmesi çok ölçülü bir yaklaşım olarak değerlendirilmiştir $(5,21)$. Bu yeni yaklaşımlar konusunda literatürde yeterli kanıt düzeyi bulunmamakla beraber şu zamana kadarki çalışmalar etkili ve güvenilir yöntemler olduğu yönünde sonuç vermiştir. AN tanısıyla yatırılarak izlenen 310 ergenin geriye dönük olarak tarandığı bir çalışmada günde 1400 kkal'den daha yüksek kalori ile başlanması daha kısa yatış süresi ile ilişkili bulunmuş; ancak daha hızı kilo alımına ve artmış RFS ya da hipofosfatemi riskine neden olmadığı gösterilmiştir. Bu çalışmada hipofosfatemi gelişimi malnutrisyon derecesi ile ve alınan kaloriden ve günlük kalori artımından çok diyet içeriğindeki toplam kalorinin \%40'ın üzerinde karbonhidrat içermesi ile ilişkilendirilmiştir (22). Hastanemizde uygulanan beslenme protokolüne göre de yeniden beslenme döneminde beslenme içeriği \% 50-55 karbonhidrat, \%30-35 yağ ve \%15-20 protein olacak şekilde ayarlanmaktadır. Kullanılan enteral ürünlerin de yaklaşık \%3045'i yağ, \%45-55'i karbonhidat ve \%10'-15'i proteinden oluşmaktadır. Öte yandan literatürde bu konudaki diğer çalışmalarda hem dahil edilen hasta sayıları yeterli değildir; hem de bazı çalışmalarda ağır malnutrisyonu olan grup çalışma dışı bırakılmıştır (23-25). Farklı beslenme protokollerini değerlendiren bir sistematik gözden geçirmede 12 yüksek kalori protokolünü (>1400 kkal/gün) uygulayan çalışmanın sonuçlarına göre yüksek kalorili beslenme protokolleri yakın izlem ve elektrolit düzeltmesi yapıldığı takdirde RFS açısından daha riskli bulunmamıştır; ancak ağır malnutrisyonu olan hasta grubunda standart uygulamayı değiştirecek yeterli kanıt bulunamamıştır (5). Genel olarak daha agresif beslenme protokolleri benimsenmeye başlanılsa da, beslenme protokolünün her hasta özelinde değerlendirilmesi ve özellikle ağır malnutrisyonlu hasta grubunda dikkatli olunması önerilmektedir (4).

Yeme bozukluğu hastalarında malnutrisyon süresinin RFS gelişimine etkisini araştıran bir çalışmada akut (3 ay ve daha kısa süreli) ve kronik malnutrisyonu (3 aydan daha uzun süreli) olan hastaların kilo alımı, medikal stabilizasyon ve elektrolit dengesizliği oranı açısından aralarında fark bulunmamıştır (26). Bizim çalışmamızda malnutrisyon süresi hesaplanmamıştır; ancak beslenme kısıtlaması süresi uzadıkça hipofosfatemi gelişme riski ve şiddeti anlamlı olarak artmıştır.

Bizim çalışmamızda enteral beslenme ile nazogastrik sonda ile beslenmenin hipofosfatemi yönünden bir farklı olmadığı saptanmıştır. Benzer şekilde bu konuda yapılmış bir sistematik literatür gözden geçirmesinde, her ne kadar çalışmaların çoğu tasarımı ve kullanılan yöntemler açısından yeterli kanıt düzeyi sunmasa da, nazogastrik sonda ile beslenmenin artmış yan etki ile ilişkili olmadığı, ve iyi tolere edilebilen güvenilir bir yöntem olduğu sonucuna varımıştır (27).

Profilaktik fosfor kullanımının RFS'yi engellemedeki rolü tartışma konusudur. Bazı kliniklerde refeeding dönemi boyunca profilaktik günlük fosfor desteği önerilirken, diğer kliniklerde bizim hastanemizde uygulanan protokole benzer şekilde laboratuvar değerlerin yakın takibi ve serum fosfor düzeyi normal sınırların altında düştüğünde destek verilmesi önerilmektedir (28-30). Yapılan bir çalışmada klinisyenlerin \%15'i yatış başlangıcında profilaktik fosfor desteği verirken, \%82'si hastanın laboratuvar bulgularına göre fosfor başlamaktadır (29). Profilaktik fosfor desteği verilirken de günlük serum elektrolitlerinin takip edilmesi gerekliliği, fosfor desteğinin RFS'de görülen diğer sıvı-elektrolit bozuklularının ve diğer medikal komplikasyonların önüne geçemeyecek olması ve fazla tedavi yapma riski bu uygulama konusundaki tartışma noktalarından biridir. Öte yandan RFS sırasındaki hipofosfateminin önüne geçilebilme olasılığının değeri ve bu uygulamaya yönelik yapılan çalışmalarda herhangi bir yan etki izlenmemiş olması bu yönteminin artılarıdır (7). AN tanısı ile izlenen 70 ergenin dahil edildiği bir çalışmada ortalama 1780 kkal ile beslenme desteği başlatılmış ve tüm hastalara profilaktik fosfor desteği verilmiştir. Bu yöntemin iyi tolere edildiği ve hiçbir hastada hipofosfatemi gelişmediği saptanmıştır (28). Ancak 
çalışmaya dahil edilen hastaların ortalama BKI değerlerinin o yaş ve cinsiyete göre 50. persentildeki BKI değerine oranının (\%mBKi) \%83.5 olması nedeniyle RFS açısından daha az risk taşımaları göz önünde bulundurulmalıdır. Özellikle ağır malnutrüsyonu olan hastaların fosfor seviyelerinin günlük takibi ve fosfor desteğinin uygun şekilde verilmesi çok önemlidir.

$\mathrm{Bu}$ çalışmanın geriye dönük olarak yapılmış olması, RFS döneminde görülebilecek hipokalemi, hipomagnezemi gibi diğer elektrolit bozukluklarına ve metabolik ve klinik değişikliklere bakmamış olması kısıtllıklar arasında yer almaktadır.

Sonuç olarak hipofosfatemi gelişimine neden olan etmenler çalışmamızda yaş, hastalık başlangıcından yatışa kadar geçen süre, bu sürede kaybedilen vücut ağırlığı miktarı ve yüzdesi ve yatış sırasındaki BKi z skoru olarak belirlenmiştir. Fosfor düzeyine göre gruplar karşlaştıııldığında da hipofosfatemi şiddetini aynı etmenler etkilemektedir. Bu sonuçlar malnutrisyon derecesinin ve hastallk șiddetinin yeniden beslenme döneminde hipofosfatemi gelişimine etkisine dikkati çekmektedir. Yeniden beslenme protokolünün her hasta özelinde değerlendirilmesi ve özellikle ağır malnutrisyonlu hasta grubunda daha dikkatli olunması çok önemlidir. Refeeding döneminde her gün serum elektrolitlerinin kontrol edilmesi gerekliliği, fosfor profilaksisinin diğer RFS komplikasyonlarının önüne geçemeyecek olması ve tedavinin hastanın klinik durumuna ve fosfor düzeyine göre belirlenmesi gerekliliği nedeniyle bizim kliniğimizde refeeding dönemi boyunca elektrolit seviyelerinin günlük takibi ve serum fosfor düzeyine göre uygun fosfor desteğinin başlanması önerilmektedir.

\section{Finansal Kaynak}

Bu çalışma sırasında, yapılan araştırma konusu ile ilgili doğrudan bağlantısı bulunan herhangi bir ilaç firmasından, tıbbi alet, gereç ve malzeme sağlayan ve/veya üreten bir firma veya herhangi bir ticari firmadan, çalıșmanın değerlendirme sürecinde, çalışma ile ilgili verilecek kararı olumsuz etkileyebilecek maddi ve/veya manevi herhangi bir destek alınmamıștır.

\section{Çıkar Çatışması}

Bu çalsşma ile ilgili olarak yazarların ve/veya aile bireylerinin çıkar çatışması potansiyeli olabilecek bilimsel ve tıbbi komite üyeliği veya üyeleri ile ilişkisi, danışmanlık, bilirkișilik, herhangi bir firmada çalışma durumu, hissedarlık ve benzer durumları yoktur.

\section{KAYNAKLAR}

1. Kraft MD, Btaiche IF, Sacks GS. Review of the refeeding syndrome. Nutr Clin Pract 2005;20:625-33.

2. Academy of Eating Disorders. Academy for Eating Disorders Report 2016, 3rd Edition: Eating Disorders, A Guide to Medical Care. Erişim tarihi: 25 July 2019. Available from: https://www. aedweb.org/resources/publications/medical-care-standards
3. Bargiacchi A, Clarke J, Paulsen A, Leger J. Refeeding in anorexia nervosa. Eur J Pediatr 2019;178:413-22.

4. Sachs K, Andersen D, Sommer J, Winkelman A, Mehler PS. Avoiding medical complications during the refeeding of patients with anorexia nervosa. Eat Disord 2015;23:411-21.

5. Garber AK, Sawyer SM, Golden NH, Guarda AS, Katzman DK, Kohn MR, et al. A systematic review of approaches to refeeding in patients with anorexia nervosa. Int J Eat Disord 2016;49:293-310.

6. Whitelaw M, Gilbertson H, Lam PY, Sawyer SM. Does aggressive refeeding in hospitalized adolescents with anorexia nervosa result in increased hypophosphatemia? J Adolesc Health 2010;46:57782.

7. Norris ML, Spettigue WJ, Katzman DK. Update on eating disorders: current perspectives on avoidant/restrictive food intake disorder in children and youth. Neuropsychiatr Dis Treat 2016;12:213-8.

8. Redgrave GW, Coughlin JW, Schreyer CC, Martin LM, Leonpacher $\mathrm{AK}$, Seide $\mathrm{M}$ et al. Refeeding and weight restoration outcomes in anorexia nervosa: Challenging current guidelines. Int J Eat Disord 2015;48:866-73.

9. Center for Disease Control and Prevention. CDC Growth Charts: Z-score data files. Erişim tarihi: 27 Temmuz 2019. Available from: https://www.cdc.gov/growthcharts/zscore.htm

10. Becker PJ, Nieman Carney L, Corkins MR, Monczka J, Smith E, Smith SE, et al. Consensus statement of the Academy of Nutrition and Dietetics/American Society for Parenteral and Enteral Nutrition: indicators recommended for the identification and documentation of pediatric malnutrition (undernutrition). J Acad Nutr Diet 2014;114:1988-2000.

11. Sociery for Adolescent Health and Medicine. Refeeding hypophosphatemia in hospitalized adolescents with anorexia nervosa: a position statement of the Society for Adolescent Health and Medicine. J Adolesc Health 2014;55:455-7.

12. Ornstein RM, Golden NH, Jacobson MS, Shenker IR. Hypophosphatemia during nutritional rehabilitation in anorexia nervosa: implications for refeeding and monitoring. J Adolesc Health 2003;32:83-8.

13. Clark CL, Sacks GS, Dickerson RN, Kudsk KA, Brown RO. Treatment of hypophosphatemia in patients receiving specialized nutrition support using a graduated dosing scheme: results from a prospective clinical trial. Crit Care Med 1995;23:1504-11.

14. Society for Adolescent Health and Medicine, Golden NH, Katzman DK, Sawyer SM, Ornstein RM, Rome ES, et al. Position Paper of the Society for Adolescent Health and Medicine: medical management of restrictive eating disorders in adolescents and young adults. $J$ Adolesc Health 2015;56:121-5.

15. Akgül $S$, Pehlivantürk-Kızılkan $M$, Örs $S$, Derman $O$, Düzçeker $Y$, Kanbur N. Type of setting for the inpatient adolescent with an eating disorder: Are specialized inpatient clinics a must or will the pediatric ward do? Turk J Pediatr 2016;58:641-9.

16. Cuerda C, Vasiloglou MF, Arhip L. Nutritional Management and Outcomes in Malnourished Medical Inpatients: Anorexia Nervosa. J Clin Med 2019;8.

17. Smith K, Lesser J, Brandenburg B, Lesser A, Cici J, Juenneman $R$, et al. Outcomes of an inpatient refeeding protocol in youth with Anorexia Nervosa and atypical Anorexia Nervosa at Children's Hospitals and Clinics of Minnesota. J Eat Disord 2016;4:35.

18. O'Connor G, Nicholls D. Refeeding hypophosphatemia in adolescents with anorexia nervosa: a systematic review. Nutr Clin Pract 2013;28:358-64. 
19. Brown CA, Sabel AL, Gaudiani JL, Mehler PS. Predictors of hypophosphatemia during refeeding of patients with severe anorexia nervosa. Int J Eat Disord 2015;48:898-904.

20. Kameoka N, Iga J, Tamaru M, Tominaga T, Kubo H, Watanabe SY, et al. Risk factors for refeeding hypophosphatemia in Japanese inpatients with anorexia nervosa. Int J Eat Disord 2016;49:402-6.

21. Golden NH, Katzman DK, Sawyer SM, Ornstein RM, Rome ES, Garber AK,et al. Update on the medical management of eating disorders in adolescents. J Adolesc Health 2015;56:370-5.

22. Kohn MR, Madden S, Clarke SD. Refeeding in anorexia nervosa: increased safety and efficiency through understanding the pathophysiology of protein calorie malnutrition. Curr Opin Pediatr 2011;23:390-4.

23. Garber AK, Michihata N, Hetnal K, Shafer MA, Moscicki AB. A prospective examination of weight gain in hospitalized adolescents with anorexia nervosa on a recommended refeeding protocol. J Adolesc Health 2012;50:24-9.

24. Garber AK, Mauldin K, Michihata N, Buckelew SM, Shafer MA, Moscicki AB. Higher calorie diets increase rate of weight gain and shorten hospital stay in hospitalized adolescents with anorexia nervosa. J Adolesc Health 2013;53:579-84.
25. Leclerc A, Turrini T, Sherwood K, Katzman DK. Evaluation of a nutrition rehabilitation protocol in hospitalized adolescents with restrictive eating disorders. J Adolesc Health 2013;53:585-9.

26. Chang YC, Thew M, Hettich K, Nugent M, Simpson P, Jay MS. Adolescent Inpatients With Eating Disorders: Comparison Between Acute and Chronic Malnutrition States on a Refeeding Protocol. Glob Pediatr Health 2019;6:2333794X19839780.

27. Rizzo SM, Douglas JW, Lawrence JC. Enteral Nutrition via Nasogastric Tube for Refeeding Patients With Anorexia Nervosa: A Systematic Review. Nutr Clin Pract 2019;34:359-70.

28. Leitner M, Burstein B, Agostino H. Prophylactic Phosphate Supplementation for the Inpatient Treatment of Restrictive Eating Disorders. J Adolesc Health 2016;58:616-20.

29. Schwartz BI, Mansbach JM, Marion JG, Katzman DK, Forman SF. Variations in admission practices for adolescents with anorexia nervosa: a North American sample. J Adolesc Health 2008;43:42531.

30. Gentile MG, Pastorelli P, Ciceri R, Manna GM, Collimedaglia S. Specialized refeeding treatment for anorexia nervosa patients suffering from extreme undernutrition. Clin Nutr 2010;29:627-32. 